\title{
Analysis of Critical Mathematical Thinking Ability and Adversity Quotient Students Through Realistic Mathematics Approach in SMP Negeri 3 Stabat
}

\author{
Fahrum Nisa Rani $^{1^{*}} \quad$ E. Elvis Napitupulu ${ }^{2} \quad$ Hasratuddin $^{2}$ \\ 1.Graduate Program School in Mathematics Education, State University of Medan, \\ 2.College Teacher State University of Medan, \\ J1. Williem Iskandar Psr. V Medan Estate, 20221,North Sumatera, Indonesia
}

\begin{abstract}
The aims of this study are ; (1) students 'mathematical critical thinking abilities through the Realistic Mathematics Education approach, (2) students' Quotient Adversity through the Realistic Mathematics Education approach, and (3) difficulties in critical thinking experienced by students in solving mathematical problems through approaches Realistic Mathematics Education. Research subjects class VII-I of SMP Negeri 3 Stabat totaling 32 students. This research is a qualitative descriptive study. The instruments of this study were tests of mathematical critical thinking skills, ARP (Adversity Response Profile) and interview guidelines. Data analysis was performed using the Miles and Huberman models. The results showed: (1) Students 'mathematical critical thinking abilities through the Realistic Mathematics Education approach showed $25 \%$ were in the low category. Then the moderate category were 11 students or $34.375 \%$. Furthermore for the high category there were 13 students or 40.625\% (2) Adversity Quotient students through the Realistic Mathematics Education approach that as many as 18 students are in the range of Adversity Quotient classified as Climber, as many as 6 students with the criteria for transitioning Camper to Climber, then 8 students for the Camper criteria with a percentage of $25 \%$, and subsequently there are no students with respectively the criteria for switching from Quitter to Camper or Quitter (3) difficulties experienced by students in solving mathematical problems through the Realistic Mathematics Education approach have difficulty understanding concepts, difficulties in applying principles, and also difficulties in verbal matters.
\end{abstract}

Keywords: Mathematical Critical Thinking Ability, Adversity Quotient, Realistic Mathematics Education DOI: $10.7176 / \mathrm{JEP} / 11-17-17$

Publication date:June 30th 2020

\section{Introducing}

Education is a measure of the progress of a nation. Education is really needed to create the next generation of the nation that is qualified and has skills. With education, it can change a person's way of thinking. But in reality, the quality of education in Indonesia is still low. According to data from the Human Development Index (HDI) in 2017 released by UNDP (United Nations Development Program) which measures the success of education, economy and quality of the nation that "The quality of Indonesian education has a score of 0.694 which is still below the world average of 0.728 ". Therefore, one of the efforts to improve the quality of Indonesian education is by creating high quality human resources. High human resources are characterized by the existence of human resources who have reliable ability to adapt to face the changing times that are getting faster and have the ability to master science and technology. To master this requires strong mathematics from an early age. Mathematics has an important role in various aspects of life. Many problems and activities in daily life that must be solved using mathematics. According to Hasratuddin (2018: 37) that;

Mathematics is a product of human intellectual thinking. Intellectual thinking can be encouraged from mere thinking problems as well as from problems involving real-life everyday. In such mathematics it is also referred to as human life and a means to train for thinking.

However, most students actually consider mathematics as a difficult, menotonous, and frightening subject. Students' negative assumptions about mathematics also have a negative impact on student achievement in learning mathematics. This can be seen in the results of the 2015 Trends In International Mathematics and Science Study (TIMSS) conducted for junior high school students with the characteristics of high cognitive level questions that can measure critical thinking skills showing that Indonesian students consistently fall below the ranks with a score of 397.In the results of the study, Indonesian students were weak in all aspects of content and cognitive. In addition, based on the results of the 2015 Program for International Student Assessment (PISA), the mathematical abilities of Indonesian students reached a score of 386 points. From these results it can be concluded that learning and mathematical problems applied in Indonesia differ from those that are standardized at the international level, so students are not accustomed to questions with TIMSS and PISA standards where the questions use critical thinking processes in solving.

Realizing this, critical thinking skills are very important for students to learn. Normaya (2015: 93) which 
states that "Critical thinking is rational thinking in assessing something". Before making a decision or taking an action, do as much information as possible about it. Another opinion from Glaser (in Fisher, 2009: 3) also defines that "Critical thinking is an attitude of wanting to think deeply about problems - based on supporting evidence and the subsequent conclusions that result". So it can be concluded that critical thinking is thinking logically using reasoning based on empirical evidence. According to Facione (2015: 5) that there are indicators of critical thinking, namely interpretation, analysis, evaluation, and inference. But the reality of students' critical thinking towards learning mathematics is still low. This can be seen from Hasratuddin's research (2010: 20) which found that in junior high schools in Medan students' cognitive cognitive abilities were still low, especially in their critical thinking abilities. The lack of students 'mathematical critical thinking skills is caused by the inability to provide valid arguments or reasons in answering or solving problems, even though the answers given are correct and the mathematical problem solving process is still not right, so this can be said that students' critical thinking skills are still relatively low. Then in research conducted by Rajagukguk, (2016: 1) shows that students' critical thinking skills are more in the medium category with $38.71 \%$.

This is also in line with preliminary studies that have been conducted by researchers at Stabat 3 Public Middle School to determine students' initial abilities in mathematical critical thinking at the school. The students shows the level of critical thinking ability of students obtained mathematics is not in accordance with the indicators of critical thinking. From the explanation, it shows that students have not maximized critical thinking in solving the problem. it can be seen that students have not been able to meet several critical thinking indicators, namely interpretation, analysis, evaluation and inference. Indicators of interpretation can be seen that students can not understand the problems shown by writing or expressing the intent of a problem situation that is not to make what is known and asked of the problem, but students directly make a mathematical model of the problem. In the analysis indicators students also have not been able to

analyze to clarify conclusions based on the relationship between information and concepts with questions in the problem or students have not been able to identify the relationships between questions and concepts given. As for indicators of inference students are able to make conclusions but are not right. In addition to these problems, students also often have difficulty thinking critically to understand contextual questions related to the material being studied, understanding concepts and students only think abstractly and there is no direct experience in constructing their own knowledge.

Difficulties in learning not only involve mathematical critical thinking skills but also come from other factors, one of which is the ability of students to respond to the material provided by the teacher, namely Adversity Quotient. The success of students in learning depends on how students cope with existing difficulties. Adversity Quotient mathematical students are low, can be seen from the response of students who easily give up when facing difficulties in solving mathematical problems. According to Ardyanti, et al (2015: 34) Adversity Quotient is an individual's ability to be able to survive in dealing with all kinds of problems, reduce obstacles and obstacles by changing the way of thinking and attitudes towards these difficulties. According to Supardi (2013: 63), Adversity Quotient is often identified with the struggle to fight adversity.From the description above, students' difficulties in learning mathematics make students' critical thinking skills and students' Adversity Quotient relatively low, therefore efforts in mathematics learning are needed. To have the ability to think critically and good Adversity Quotient in a learning is indeed not easy, but the ability to think critically and Adversity Quotient can be learned and trained. One learning that can be assumed to be able to improve students' mathematical critical thinking skills and student's Adversity Quotient is through the Realistic Mathematics Education learning approach.

\section{Literature Review}

\subsection{Critical Thinking Ability}

According to Chukwuyenum (2013: 90) "Critical thinking is a complex concept that involves cognitive skills and self-confidence, this can also be influenced by several ways that teachers use in conveying the concept of material to students". Meanwhile, according to Ennis (1991: 6) provides a definition of critical thinking as follows, "Critical thinking is reasonable, reflective thinking that is focused on deciding what to believe and do" which means critical thinking is thinking reasoned and reflective by emphasizing decision making about what that must be trusted or done.

Tanujaya (2014: 243) states that "A person is said to have the ability to think critically if he has three main things, namely: (1) attitude in responding wisely to various issues or everything that arises in his life, (2) knowledge of logical thinking methods and make sense and, (3) skills in applying these methods ". Someone who has a critical attitude component will have a certain character that is a character where a person tends to find out something that underlies decisions and actions, character that is impartial and not arbitrary, character to assess objectively against relevant facts, and character value aspects - aspects of critical thinking such as intellectual honesty, fairness, sympathetic, and objectivity. Therefore, skills and principles of critical thinking are important for critical thinkers. 
Critical thinking skills are an effective way to improve students' understanding of mathematical concepts because these skills can help in interpreting, analyzing, evaluating, and presenting logically and sequentially. So when someone has been thinking critically then has thought logically, because in critical thinking requires logical thoughts. But someone who has thought logically doesn't necessarily think critically.

Facione (2015: 5) states that there are six indicators of critical thinking ability, namely interpretation, analysis, evaluation, inference, explanation, and self-regulation. But in this study, researchers only use indicators of interpretation, analysis, evaluation, and inference.

\subsection{Adversity Quotient}

Adversity Quetient can also be used to assess the extent to which a student faces a complex problem. According to Stolz (2004: 12) argues that Adversity Quotient is used to help individuals strengthen their abilities and perseverance in facing challenges. So it can be concluded that Adevrsity Quotient is intelligence to face difficulties or obstacles and the ability to survive in various life difficulties and challenges experienced.

ARP (Adversity Response Profile) is a valid instrument to measure people's responses to difficulties. Every event in the ARP is accompanied by two statements that use a Likert scale. These statements are negative and some are positive. According to Stoltz (2004: 129) this negative statement is concerned with the score, because we pay more attention to the responses to adversity. The Adversity Quotient Scale is based on the basic aspects of Adversity Quotient according to Stoltz (2004: 141), namely: Control (ability to control the situation), Origin and Ownership (ability to bear the consequences of the situation), Reach (reach), and Endurance (endurance). Stolz (2004: 18) grouped people into 3 categories of Adversity Quetient namely quitter (low Adversity Quetient), camper (moderate Adversity Quetient), and climber (high Adversity Quetient).

\subsection{Realistic Mathematics Education}

Realistic Mathematic Education is a student-centered learning approach that puts students as subjects in learning and links learning with problems related to students' daily experiences (Kristinayanti, 2014). With the Realistic Mathematic Education learning approach students will become active in learning and the teacher as a facilitator. Realistic Mathematic Education is learning that is oriented towards students' realistic reasoning in accordance with curriculum demands which are shown to develop practical, logical, critical and honest mindset with orientation to mathematical reasoning in solving problems (Tarigan, 2006: 4).

A realistic problem does not have to be a problem that exists in the real world and can be found in everyday life but a problem is called realistic if the problem can be imagined by students. So the point is to make a problem real in students' minds. Thus various mathematical problems can be real imagined by students so that the problems faced by students in learning mathematics will become apparent in students' minds. The characteristics of the Realistic Mathematics Education approach that must be applied in the learning process (Ningsih, 2014: 78) are as follows.

a. Using the real world context (The use of contex)

b. Using models (use models, bridging by verti instruments)

c. Using student construction (Student contribution)

d. Using interactive (Interactivity)

e. Integrated with other topics (Intertining)

As for the steps in the Realistic Mathematics Education approach according to Ningsih (2014: 81) namely understanding contextual problems, explaining contextual problems, solving contextual problems, comparing and discussing answers, and concluding.

\section{Research Methodology}

This research has been conducted at SMP Negeri 3 Stabat. The subjects in this study were class VII students, amounting to 32 students. Criteria for taking subjects using criteria that are based on indicators of student ability, error answers, and unique answers. Through the terms of the indicators the student answer sheets are grouped into three categories of answers, namely (1) high ability student answer sheets; (2) medium ability student answer sheets; (3) low ability student answer sheets. The three categories of student answer sheets were each analyzed to determine student answer patterns. The instruments of this study were tests of mathematical critical thinking skills, ARP (Adversity Response Profile) and interview guidelines. Data analysis was performed using the Miles and Huberman models.

To find out the students' mathematical critical thinking skills can be done by analyzing the answers from all students. This can be analyzed by referring to the scoring guideline of critical thinking from Facione (Normaya, 2015: 93) which consists of four indicators of critical thinking skills as well as information and acquisition scores. The guidelines for scoring can be seen in the following table. 
Table 1. Guidelines for Scoring Critical Mathematical Thinking Ability

\begin{tabular}{|c|c|c|}
\hline Indicator & Description & Score \\
\hline \multirow[t]{5}{*}{ Interpretation } & Not writing the known and asked & 0 \\
\hline & Write what is known and what is asked incorrectly & 1 \\
\hline & Just write down what is known correctly or just what is asked correctly & 2 \\
\hline & Write what is known from the problem correctly but is incomplete & 3 \\
\hline & Write what is known and asked of the problem precisely and completely & 4 \\
\hline \multirow[t]{5}{*}{ Analysis } & Not make a mathematical model of the problem given but it is not right & 0 \\
\hline & Make a mathematical model of the problem given but not right & 1 \\
\hline & $\begin{array}{l}\text { Make a mathematical model of the problem given precisely without giving an } \\
\text { explanation }\end{array}$ & 2 \\
\hline & $\begin{array}{l}\text { Make a mathematical model of the problem given precisely but there are errors in } \\
\text { the explanation }\end{array}$ & 3 \\
\hline & $\begin{array}{l}\text { Make a mathematical model of the problem given correctly and give a correct and } \\
\text { complete explanation }\end{array}$ & 4 \\
\hline \multirow{5}{*}{ Evaluation } & Do not use strategy in solving problems & 0 \\
\hline & Using inappropriate and incomplete strategies in solving problems & 1 \\
\hline & $\begin{array}{l}\text { Using the right strategy in solving problems, but not complete or using strategies } \\
\text { that are not right but complete in solving problems }\end{array}$ & 2 \\
\hline & $\begin{array}{l}\text { Use the right strategy in solving problems, complete but make mistakes in } \\
\text { calculations or explanations }\end{array}$ & 3 \\
\hline & $\begin{array}{l}\text { Using the right strategy in solving problems, complete and correct in making } \\
\text { calculations / explanations }\end{array}$ & 4 \\
\hline \multirow[t]{5}{*}{ Inference } & Don't make conclusions & 0 \\
\hline & Make conclusions that are not right and do not fit the context of the problem & 1 \\
\hline & Making inaccurate conclusions, although adjusted to the context of the problem & 2 \\
\hline & Make conclusions correctly, according to context but not complete & 3 \\
\hline & $\begin{array}{l}\text { Make conclusions precisely, in accordance with the context of the problem and } \\
\text { complete }\end{array}$ & 4 \\
\hline
\end{tabular}

Modification from Facione (Normaya, 215:93)

To determine whether students meet each of the indicators of critical thinking skills or have not yet solved the problems contained in mathematical problems, it can be seen from the following percentage values.

$$
\text { Percentage value }=\frac{\text { Acquistions score }}{\text { Maximum Score }} \times 100 \%
$$

Susilowati, Sajidan, Ramli (2017:226)

The percentage value of critical thinking skills obtained from calculations is then categorized according to the following table.

Table 2. Percentage Categories of Critical Thinking Skills

\begin{tabular}{|l|l|}
\hline Interval Value (\%) & \multicolumn{1}{|c|}{ Category } \\
\hline $81,25<X \leq 100$ & Very High \\
\hline $71,50<X \leq 81,25$ & High \\
\hline $62,50<X \leq 71,50$ & Middle \\
\hline $43,75<X \leq 62,50$ & Low \\
\hline $0<X \leq 43,75$ & Very Low \\
\hline
\end{tabular}

Normaya (2015:96)

The following is a grid of students' difficulties in solving mathematical problems.

Table 3. Grid-Difficulty Students in Solving Mathematical Problems

Indicator $\quad$ Description

Difficulty in learning concepts Students find it difficult to learn mathematical concepts in solving problems

Difficulties in applying principles Students find it difficult to apply the principles they have obtained and it is difficult to apply them in solving problems

Difficulty in solving verbal problems $\quad$ Students find it difficult to solve verbal questions or story problems Sholekah et al (2017: 155)

After analyzing students' mathematical critical thinking skills as well as the difficulties experienced by students in solving mathematical problems then students' Adversity Quotient analysis can be analyzed which can 
be seen from the students' ARP (Adversity Response Profile) results. ARP contains aspects of Adversity Quotient namely Control, Origin and Ownership, Reach and Endurance. Then you can see the categories for each of these aspects. This can be seen in the table below.

Table 4. Categories of Every Aspect of Adversity Quotient

\begin{tabular}{|l|l|c|}
\hline $\begin{array}{c}\text { Adversity Quotient } \\
\text { Aspect }\end{array}$ & $\begin{array}{c}\text { Interval } \\
\text { Score }\end{array}$ & $\begin{array}{c}\text { Adversity Quotient } \\
\text { Kategory Aspect }\end{array}$ \\
\hline $\begin{array}{l}\text { Control, Origin and } \\
\text { Ownership, Reach, } \\
\text { and Endurance }\end{array}$ & $10-23$ & Low \\
\cline { 2 - 3 } & $24-37$ & Middle \\
\hline
\end{tabular}

(Stoltz, $2004: 144$ )

After scoring the results of the Adversity Response Profile (ARP) after that each aspect of the adversity quotient is categorized and then each student is categorized as having an Adversity Quotient. The following are categories of Adversity Quotient:

Tabel 5. Kategori Adversity Quotient

\begin{tabular}{|l|l|}
\hline Skor & \multicolumn{1}{|c|}{ Kategori } \\
\hline$\leq 59$ & Quitter \\
\hline $60-94$ & Switchover quitter to camper \\
\hline $95-134$ & Camper \\
\hline $135-165$ & Switchover camper to climber \\
\hline$\geq 166$ & Climber \\
\hline
\end{tabular}

(Suhartono, $2016: 65)$

\section{Results And Discussion}

In the learning process that has been carried out for four meetings in class VII-1 of SMP Negeri 3 Stabat, the ability of students to think critically and adversity quotient is better after applying the Realistic Mathematics Education approach compared to conventional learning that has been taught to students before because during learning each student is able change the context of the real world into a mathematical model, then each student gives his idea of ideas to the group in solving mathematical problems, then most students interact between students and teachers if there is a misunderstanding experienced by students. During learning through the Realistic Mathematics Education approach, student adversity quotient is better than before because there is a good struggle shown by students in solving contextual problems given and able to survive in difficult circumstances and not easily discouraged in solving these problems.

Based on the explanation above, the Realistic Mathematics Education approach can be used as an alternative learning that can develop students' mathematical critical thinking skills and student adversity quotient. This can be seen from the following explanation. Critical thinking skills test is done by students individually and directly supervised by researchers and mathematics teachers at SMP Negeri 3 Stabat. The level of critical thinking skills can be seen in the following table.

Table 6. Students' Level of Critical Mathematical Thinking Ability

\begin{tabular}{|l|c|l|l|}
\hline Interval Nilai (\%) & Number of Students & Persen-tage & Kategory \\
\hline $43,75-62,50$ & 8 & $25 \%$ & Rendah \\
\hline $62,50-71,50$ & 11 & $34,375 \%$ & Sedang \\
\hline $71,50-81,25$ & 13 & $40,625 \%$ & Tinggi \\
\hline Jumlah & $\mathbf{3 2}$ & $\mathbf{1 0 0} \%$ & \\
\hline
\end{tabular}

Based on the table, it can be seen that the level of mathematical critical thinking ability of students through the Realistic Mathematics Education approach is obtained that the number of students who get an interval of values of $43.75-62.50$ in the low category is 8 students or $25 \%$. Then the number of students who are in the interval $62.50-71.50$ with a moderate category of 11 students or $34.375 \%$. Furthermore, for the interval values of $71.50-81.25$ in the high category there were 13 students or $40.625 \%$. Meanwhile, to find out the percentage of each indicator of critical thinking from the 7 questions that have been given can be seen in the following table.

Table 7. Percentage of Each Indicator of Critical Thinking

\begin{tabular}{|c|r|}
\hline Indicators of Critical Thinking & Persentage \\
\hline Interpretation & $80,58 \%$ \\
\hline Analysis & $61,94 \%$ \\
\hline Evaluation & $57,36 \%$ \\
\hline Inference & $56,69 \%$ \\
\hline
\end{tabular}

In table 7 it can be concluded that the interpretation indicator is more dominantly mastered by students in completing the critical thinking skills test that has been given by the teacher with $80.58 \%$, while the analysis indicators of 32 students found that $61.94 \%$ of students are able to master the indicator, for evaluation indicators 
$57.36 \%$ and inference indicators with a percentage of $56.96 \%$.

Then to find out the students' Adversity Quotient seen from the ARP which consists of 30 statements consisting of 12 positive statements and 18 negative statements. Scoring on each response choice was given a score of 1,2,3,4 and 5 for the choice of answers strongly disagree (STS), Disagree (TS), Doubt (RG), agree (S) and strongly agree (SS) the negative statement, while for the positive statement given a score of 5,4,3,2, and 1 for the choice of strongly agree (SS), agree (S), Doubt (RG), Disagree (TS), and strongly disagree (STS). Adversity Quotient Scale is given after the implementation of learning using the Realistic Mathematics Education approach. Adversity Quotient results can be seen in the attachment. The Adversity Quotient Scale is given aiming to find out the Adversity Quotient of students after the implementation of learning. The following will explain the analysis of the results of the Adversity Quotient scale in table 8.

Table 8. Percentage of Student Adversity Quotient Criteria

\begin{tabular}{|l|c|l|l|}
\hline Score Interval & Number of Student & Percentage & \multicolumn{1}{c|}{ Criteria } \\
\hline$\geq 166$ & 18 & $56,25 \%$ & Climber \\
\hline $135-165$ & 6 & $18,75 \%$ & Switchover Camper to Climber \\
\hline $95-134$ & 8 & $25 \%$ & Camper \\
\hline $60-94$ & 0 & $0 \%$ & Switchover Quitter to Camper \\
\hline$\leq 59$ & 0 & $0 \%$ & Quitter \\
\hline
\end{tabular}

In this table it can be concluded that from the results of the ARP (Adversity Response Profile) that as many as 18 students are in the Adversity Quotient score range of 166 classified as Climber criteria with a percentage of $56.25 \%$, as many as 6 students are in the score range 135-165 with Camper transition criteria to Climber, then in the range of scores from 95 to 134 there were 8 students for the Camper criteria with a percentage of $25 \%$, and subsequently there were no students in the score range 60-94 and 59 with each of the criteria for switching from Quitter to Camper or Quitter. Then for aspects of Adversity Quotient students can be seen in the following table.

Table 9. Students Adversity Quotient Ascpect

\begin{tabular}{|l|c|c|}
\hline \multicolumn{1}{|c|}{ Adversity Quotient Aspect } & Score Average & Category \\
\hline Control & 28,75 & Medium \\
\hline Origin & 29,91 & Medium \\
\hline Ownership & 29,71 & Medium \\
\hline Reach & 29,81 & Medium \\
\hline Endurance & 29,43 & Medium \\
\hline
\end{tabular}

\section{Conclusions}

The research put forward several conclusions as follows.

1. Students' mathematical critical thinking ability through the Realistic Mathematics Education approach is obtained that the number of students who get 8 students for the low category. Then the number of students in the moderate category was 11 students. Furthermore for the high category there were 13 students. Critical thinking indicators in the form of interpretation are more dominant.

3. Adversity Quotient of students through the Realistic Mathematics Education approach that as many as 18 students belong to the Climber as many as 6 students with Camper to Climber transition criteria, then 8 students for the Camper criteria and subsequently there are no student criteria for transition from Quitter to Camper or Quitter. for aspects of Adversity Quotient namely Control, Origin and Ownership, Reach, and Endurance in the category of "medium".

4. Difficulties experienced by students in solving mathematical problems through the Realistic Mathematics Education approach have difficulty understanding concepts, difficulties in applying principles, and also difficulties in verbal problems.

\section{References}

Ardyanti., Shinta Ika., dan Harini Esti. (2015). Hubungan Antara Adversity Quotient, Self Efficacy dan Kebiasaan Belajar Dengan Prestasi Belajar Matematika Siswa Kelas X Kecantikan SMK Negeri SeKecamatan Umbulharjo. Jurnal Pendidikan Matematika, 3(1): 33 - 44

Chukwuyenum, Asuai Nelson. (2013). Impact of Critical Thinking on Performance In Mathematics Among Senior Secondary School Students In Lagos State. IOSR Journal of Research \& Method In Education, 3(5): $18-25$

Ennis, Robert H. (1991). Critical Thinking : A Streamlined Conception. Teaching Philosophy, 14. 15 - 24.

Facione, Peter A. (2015). Critical Thinking : What Is and Why It Counts. Insight Assesment.

Fisher, Alec. (2009). Berpikir Kritis Sebuah Pengantar. Jakarta : Erlangga

Hasratuddin. (2018). Mengapa Harus Belajar Matematika. Medan : Perc EDIRA

.(2010). Peningkatan Kemampuan Berpikir Kritis Siswa SMP Melalui pendekatan Matematika 
Realistik. Jurnal Pendidikan Matematika, 4(2)

Kristinayanti, Ni Luh Putu, Wayan Wiarta, dan Rini Kristiantari. (2014). Model Pembelajaran Realistic Mathematics Education Berbantuan Media Visual Berpengaruh Terhadap Hasil Belajar Matematika Siswa Kelas V SD Gugus 1 Abiansemal. E Journal PGSD Universitas Pendidikan Ganesha, 2(1): 1 - 10

Mullis, Martin, Foy dan Hooper. (2015). Trends in International Mathematics And (TIMSS). IEA : TIMSS \& PIRLS International Study Center

Ningsih, Seri. (2014). Realistic Mathematics Education : Model Alternatif Pembelajaran Matematika Sekolah. Jurnal IAIN Antasari, 1(2): 73 - 94

Normaya. Karim. (2015). Ketuntasan Hasil Belajar Melalui Pendekatan Realistic Mathematics Education (RME). Jurnal Ilmiah Didaktika, 13(2): 92 - 104

OECD, PISA 2015 Result (Volume II): Policies And Practices For Successful Schools.PISA OECD Publishing, Paris.

Rajagukguk, Wamington dan Kms. Muhammad Amin Fauzi. (2016). Pengembangan Bahan Ajar Matematik Berbasis Inkuiri Berbantuan Multi Media untuk Meningkatkan Kemampuan Berpikir Kritis Siswa SMA SeProvinsi Sumatera Utara. Prosiding Seminar Nasional Matematika. Volume 11. ISSN 1907 - 3909.

Sholekah, Anggreini, dan Waluyo. (2017). Analisis Kesulitan Siswa Dalam Menyelesaikan Soal Matematika Ditinjau Dari Koneksi Matematis Materi Limit Fungsi. Jurnal Wacana Akademia, 1(2): 151 - 164

Stoltz, Paul G. (1997). Adversity Quotient: Mengubah Hambatan Menjadi Peluang. Translation by T.Hermaya. (2004). Jakarta: Grasindo.

Suhartono. (2016). Adversity Quotient Sebagai Acuan Guru Dalam Memberikan Soal Pemecahan Masalah Matematika. INOVASI, 18(2): $62-70$

Supardi. 2014. Pengaruh Adversity Quotient Terhadap Prestasi Belajar Matematika. Jurnal Formatif, 3(1) : 61 71

Susilowati, Sajidan, Ramli. (2017). Analisis Keterampilan Berpikir Kritis Siswa Madrasah Aliyah Negeri di Kabupaten Magetan. Seminar Nasional Pendidikan SAINS. 223 - 231

Tanujaya, Benidiktus. (2014). Pengukuran Keterampilan berpikir Kritis Siswa SMA Dalam Pembelajaran Matematika. Proceeding Seminar Nasional Psikometri.

Tarigan, Daitin. (2006). Pembelajaran Matematika Realistik. Jakarta : Depdiknas

United Nations Developmennt Programme (UNDP). 2017. Human Development Report. 